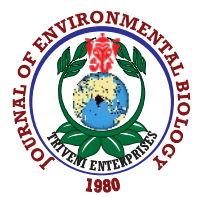

\title{
Length-weight relationship, feeding traits and nutritional value of mahi mahi (Coryphaena hippurus) in the south-eastern Arabian Sea
}

\author{
K. Assana', R. Mridula, K.M. Rajesh ${ }^{2 *}$ and T.A. Shaik ${ }^{3}$ \\ ${ }^{1}$ Department of Fisheries Resources and Management, College of Fisheries, Mangalore-575 002, India \\ ${ }^{2}$ ICAR-Central Marine Fisheries Research Institute, Mangalore Research Centre, Mangalore-575 001, India \\ ${ }^{3}$ Department of Aquatic Animal Health Management, College of Fisheries, Mangalore-575 002, India \\ *Corresponding Author Email : rajeshmkm3@rediffmail.com
}

\section{Abstract}

Aim: The present study was conducted to investigate the length-weight relationship, food and feeding behaviour and proximate composition of an oceanic epipelagic fish, Coryphaena hippurus landed along Karnataka, south-eastern Arabian Sea.

\begin{abstract}
Methodology: Length-weight relationship, feeding and proximate composition of C. hippurus was studied for a period of one year. The size composition, feeding intensity, frequency, occurrence and index of relative importance (IRI) was determined for each diet component in the stomach. Monthly proximate composition in the dolphin fish was estimated.
\end{abstract}

Results: The fork length of the specimens of $C$. hippurus collected along Karnataka coast ranged from $30-123 \mathrm{~cm}$ and fishes having length range from $33-73 \mathrm{~cm}$ represented $79 \%$ of the total fish sampled. The estimated $b$ values of $C$. hippurus for both males and females were less than 3 which indicated negative allometric growth; the fish grows faster in length than weight. The most dominant item recorded in the gut of $C$. hippurus was pelagic and mesopelagic teleosts. Cephalopods (squids, cuttlefish and octopus) were the second important food constituent while crustaceans consisting of crabs and shrimps formed very less quantity.

Interpretation: Information on length-weight relationship, feeding behaviour and proximate composition of mahi mahi would be useful for developing suitable management plans for the conservation and judicious exploitation of this commercially important resource.

Key words: Dolphin fish, Food and feeding, Index of relative importance, Karnataka, Proximate composition

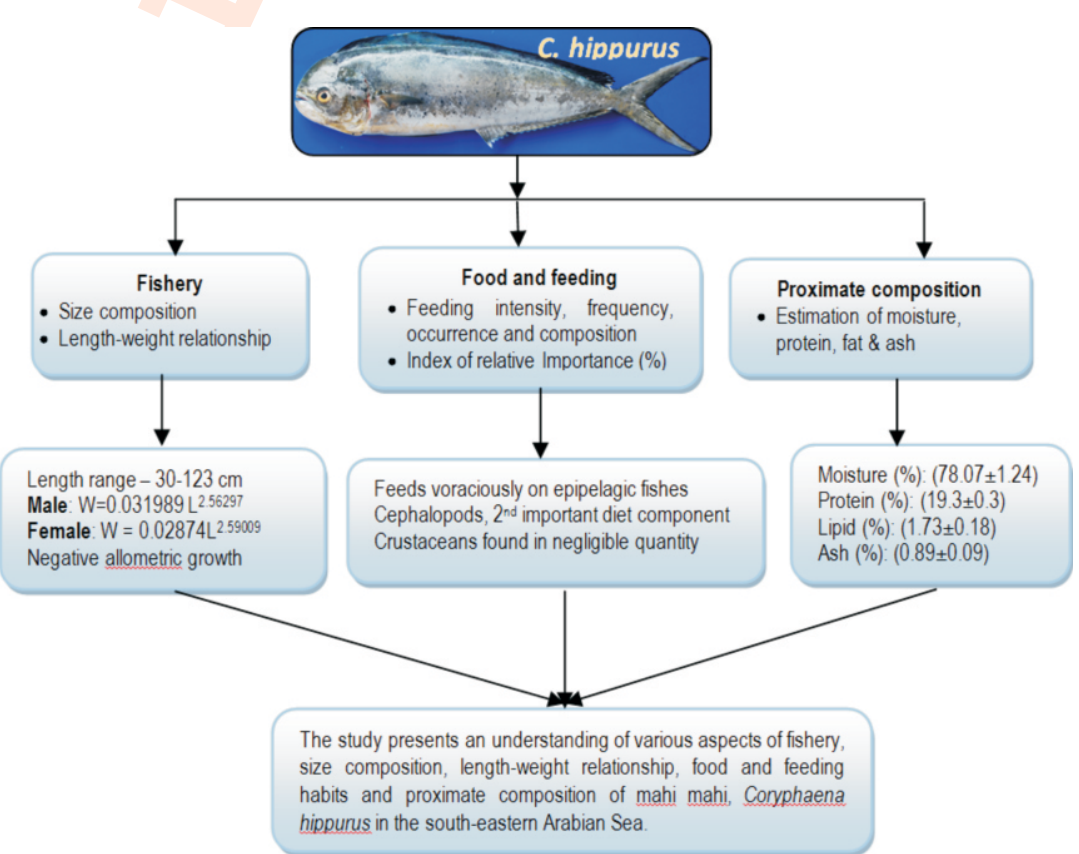

How to cite : Assana, K., R. Mridula, K.M. Rajesh and T.A. Shaik: Length-weight relationship, feeding traits and nutritional value of mahi mahi (Coryphaena hippurus) in the south eastern Arabian Sea. J. Environ. Biol., 41, 776-781 (2020). 


\section{Introduction}

Coryphaena is the only genus in the family Coryphaenidae comprising of two species $C$. hippurus and $C$. equiselis. C. hippurus, an epipelagic highly migratory species generally known as mahi-mahi, dolphin fish or Dorado is a wellknown food and game-fish with cosmopolitan distribution occurring worldwide in tropical and subtropical seas (Gatt et al., 2015). It is typically found in pelagic habitats, where they form schools and have a tendency to aggregate near natural and artificial floating objects (Castriota et al., 2007). Dolphin fish is considered as an economically important fish species all along its distributional areas as they support artisanal, recreational and commercial fisheries (Olson and Galvan-Magana, 2002).

From the ecological perspective, dolphin fish plays an important role, as it is a highly pelagic fish species located at the top portion of the food chain, contributing to the balance of the marine ecosystem. Growth rates of this fish can be as high as 4 $\mathrm{mm}$ per day, but vary considerably (Oxenford and Hunte, 1983) depending on location and season (Oxenford, 1999). The remarkable fast growth rate and high turnover of this species has probably made it less susceptible to the act of overfishing as compared to other long-lived slow maturing fishes (FWRI, 2008) and are included under the category 'least concern' in the IUCN Redlist (Collette et al., 2011). In trophic terms, C. hippurus is a top predator in the pelagic ecosystem (Massutí et al., 1998), and fishing activities may provoke top-down consequences on pelagic food resources, new insight on this topic can provide useful ecological information, which can also be exploited for an ecosystem approach to pelagic fish management.

Dolphin fish is an important part of the pelagic food web and ecosystem with a feeding strategy that is more opportunistic rather than selective. It removes considerable amount of tertiary production from an ecosystem by consuming approximately 5$6 \%$ of its body weight per day (Olson and Galvan-Magana, 2002). Extremely diverse prey array was recorded from the gut of this species from different parts of the world according to the season and geographical location. Hence, region specific studies provide knowledge on ecology and biology of the resource which is essential for its judicious management and conservation. However, the detailed study on food and feeding habits and proximate composition of this economically important fish species in Indian waters are meagre. Therefore, an investigation was initiated to study the length-weight relationship, food and feeding habits and proximate composition of $C$. hippurus in the south-eastern Arabian Sea.

\section{Materials and Methods}

Specimens of $C$. hippurus landed by various gears (trawls, purse seines, long lines and gillnets) were collected on weekly basis from August 2017 to May 2018 from two major fishing harbours along Karnataka Coast located at Mangalore and Malpe. The collection of sample could not be done during June and July due to the monsoon fishing ban for the operation of mechanised fishing vessels. Specimens were preserved in an insulated icebox and shifted to the laboratory of the Mangalore Research Centre of Central Marine Fisheries Research Institute (CMFRI, Mangalore, India) for further analysis.

Fork length $(\mathrm{FL})$ and body weight of 77 males and 270 female $C$. hippurus were measured to the nearest $0.1 \mathrm{~cm}$ and 0.1 $\mathrm{g}$ accuracy, respectively. The length-weight relationship (LWR) was estimated by the formula of Le Cren (1951).

$$
W=a(F L)^{b}
$$

where, $W$ is the total body weight $(\mathrm{g}), \mathrm{FL}$ is the fork length $(\mathrm{cm}), \mathrm{a}$ is a coefficient related to body weight and $b$ is an exponent. Analysis of covariance (ANCOVA) was used to compare the length-weight relationship of males and females (Snedecor and Cochron, 1967).

Food and feeding habit was studied based on the analysis made on 347 fishes after careful dissection. Stomachs taken out from the individual fishes were classified for the fullness of the stomach based on the visual observations as empty, trace, one-fourth full, half full, three-fourth full and full. The total weight of the content in the stomachs was recorded and prey items were broadly categorized into fishes, crustaceans and cephalopods. Weight of each prey item was recorded separately and ranking was given to various food items found in the stomach using points method. The prey items present in the stomach were identified up to the generic/species level following the keys and identifying descriptions (Froese and Pauly, 2017) and the numbers of identified food items were counted. Partially digested and unidentified remains of fish were grouped as unidentified fish remains. The index of relative importance (IRI) of each diet component in the stomach was determined following the protocol of Pinkas et al. (1971) on the basis of three indices: wet weight percentage of each food item $(\% \mathrm{~W})$ to the total weight of all the food items in the gut; percentage of the number $(\% \mathrm{~N})$ of each food item to the total number of all identified food items; and frequency of occurrence (\%F) of each food item to the total number of guts examined. The IRI was calculated as: $I R I=(\% N+\% W) \times \% F$. Proximate composition of fish (Protein, fat and Ash content) was determined by following the method of AOAC (2010).

\section{Results and Discussion}

The fork length of $C$. hippurus specimens collected along Karnataka coast ranged between 30 and $123 \mathrm{~cm}$ and the fishes having length ranging from $33-73 \mathrm{~cm}$ represented $79 \%$ of the total fish sampled (Fig. 1). Among the different length class, the length range from 59 to $63 \mathrm{~cm}$ represented $12.6 \%$ followed by the length range of $49-53 \mathrm{~cm}(11.8 \%), 64-68 \mathrm{~cm}(9.9 \%), 54-58 \mathrm{~cm}(8.5 \%)$, $74-78 \mathrm{~cm}(8.5 \%)$ and $30-33 \mathrm{~cm}(8.3 \%)$. Modal lengths were 63 


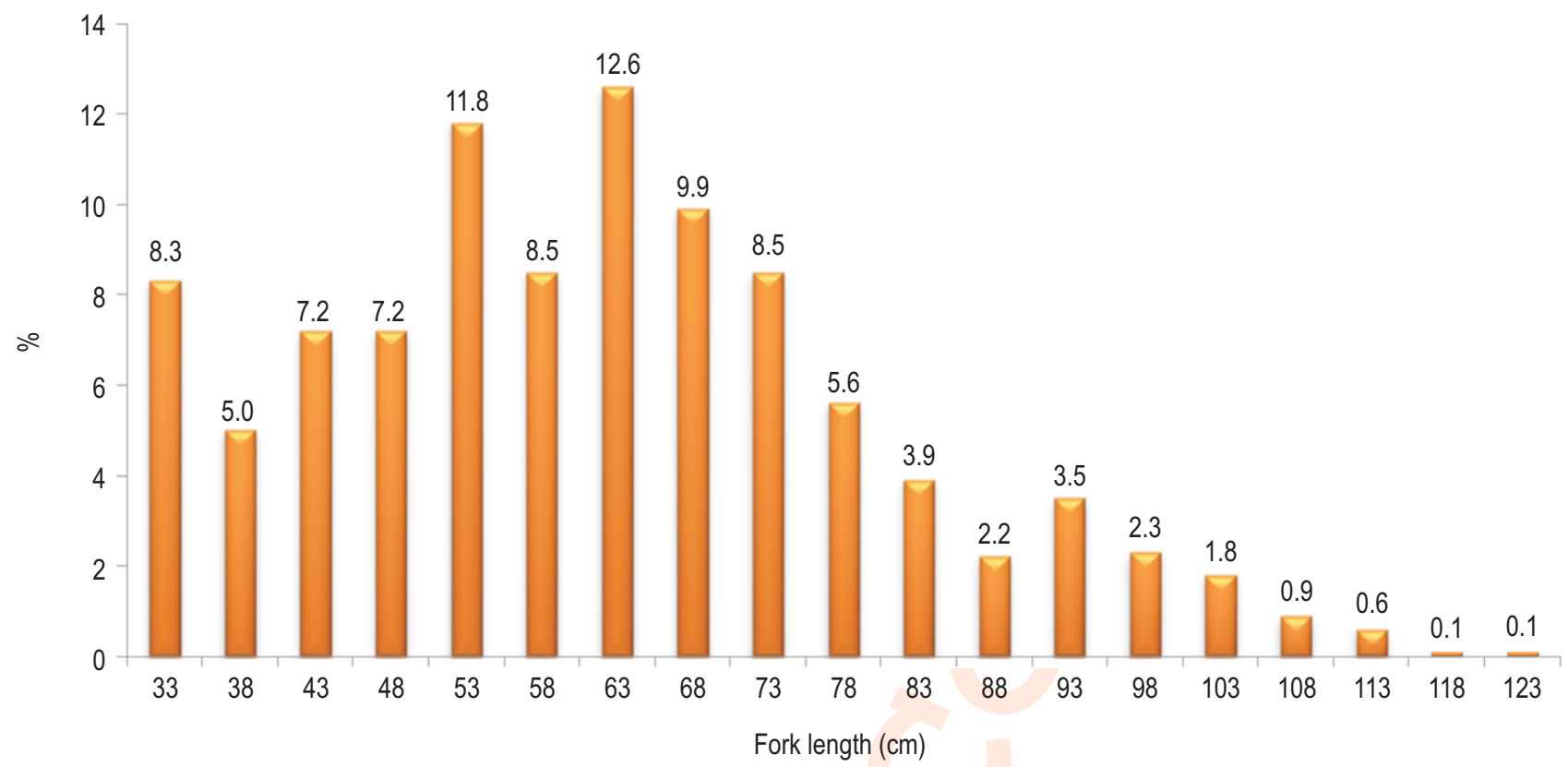

Fig. 1 : Size composition of C. hippurus collected during 2017-18 in south-eastern Arabian Sea along Karnataka Coast.

and $53 \mathrm{~cm}$ and the estimated annual mean length was $74.2 \mathrm{~cm}$. The fork length range recorded in the present study is almost similar to the previous reports from east coast of Taiwan (ChuenChi Wu et al., 2001) and west coast of India (Vinod Kumar et al., 2017) where a size range of $26.5-139 \mathrm{~cm}$ and $27.5-135 \mathrm{~cm}$ were recorded, respectively. In contrast, a higher length range of 41.7$177 \mathrm{~cm}$ FL was reported from the Eastern Pacific Ocean (Olson and Galvan-Magana, 2002).

The LWR for male and female $C$. hippurus are given in Fig. 2. The estimated $b$ values of $C$. hippurus for both males and females were less than 3 which indicated negative allometric growth; the fish grows faster in length than weight. The estimated allometric coefficient $b$ did not differ significantly between the sexes and was found within the normal expected range of 2.5-3.5 for teleosts (Froese, 2006). The LWRs of C. hippurus in the present study is in agreement with the previous published information from the Eastern-Pacific Ocean (Olson and GalvanMagana, 2002), Central Mediterranean (Gatt et al., 2015) and West coast of India (Vinod Kumar et al., 2017).

Of the 347 guts of C. hippurus analysed, only 191 $(55.56 \%)$ had food in varied quantity and $156(44.44 \%)$ were having empty stomachs. Twenty eight fishes (8.02\%) were having trace (very less) amount of food, 75 fishes $(21.49 \%)$ with onefourth quantity, 39 fishes (11.17\%) with half, 10 fishes (2.87\%) having three-fourth and $41(11.75 \%)$ fishes were having full food content in their stomach. The higher percentage of empty stomach observed in C. hippurus in this study is in line with the previous observations with $50.3 \%$ and $40 \%$ empty stomachs from Eastern-Pacific Ocean (Olson and Galvan-Magana, 2002) and
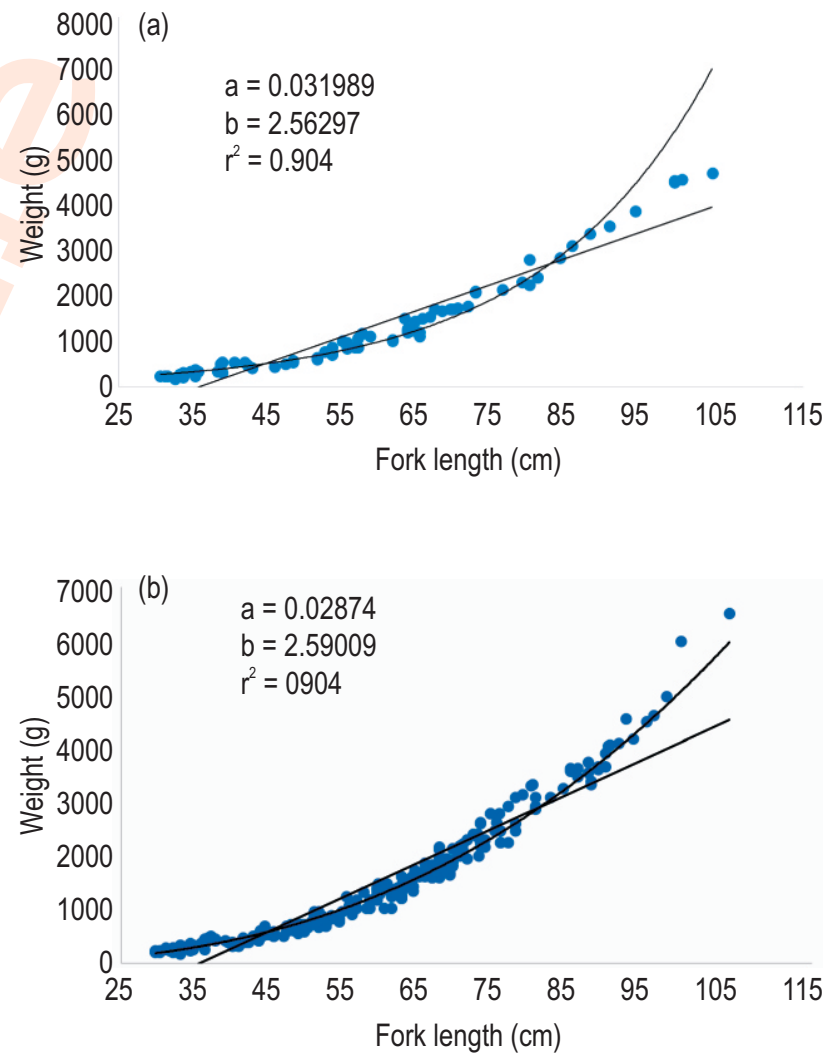

Fig. 2 : Length-weight relationship of $C$. hippurus (a) male and (b) female collected during 2017-18 in south-eastern Arabian Sea along Karnataka coast. 
west coast of India (Vinod Kumar et al., 2017), respectively. Incidences of higher proportion of empty stomachs is a characteristic of piscivorous fishes (Juanes and Conover, 1994) and lesser quantity of food in the stomach and higher proportion of empty stomachs could be attributed to the high calorie content of the diet which demands limited intake of food items (Rajesh et al., 2019).

The prey of $C$. hippurus belonged to three major taxonomic group such as fishes, cephalopods and crustaceans (Table 1). The most dominant food item by frequency of occurrence $(72.13 \%)$, weight $(88.10 \%)$, number $(78 \%)$ and $\%$ IRI $(91.22 \%)$ was teleosts followed by cephalopods $(24.59 \%, 9.49$, $21 \%$ and $8.4 \%$, respectively, in terms of occurrence, weight, number and IRI) and crustaceans (3.28\%, 2.41\%, 1.0\% and 0.34 $\%$ in terms of frequency of occurrence, weight, number and IRI, respectively). The results of this study indicated that $C$. hippurus like other pelagic fishes predate opportunistically on several prey items (Oxenford, 1999). The study has shown that \% IRI was high for teleosts $(91.22 \%)$ compared to cephalopods (8.44) and crustaceans (0.34). Predominance of teleosts in the diet of dolphin fish has been reported from Eastern-Pacific Ocean (Olson and Galvan-Magana, 2002) and along the coast of Rio De Janerio, Brazil (Pimenta et al., 2014). Almost half of the (48.86\%) teleosts consumed were in the form of semi-digested matter, as the fishes caught in gillnet and longline stays alive for long time and during this period the digestion of prey item continues (Boggs, 1992).

The result of IRI indicated that this carnivorous fish gives preference to the pelagic and mesopelagic fish species such as Decapterus russelli, Bregmaceros sp., Priacanthus spp., Rastrelliger kanagurta, Encrasicholina devisi, Lagocephalus inermis, Saurida sp. and Sardinella longiceps. The predatory activity of dolphin fish plays an important role in the pelagic system in transferring energy between epipelagic and mesopelagic environments in the marine food web (Castriota et al., 2007). Epipelagic fishes as common prey item in the

Table 1 : Frequency, number, weight and Index of relative importance (IRI) of food items in the diet of C. hippurus collected during 2017-18 in southeastern Arabian Sea along Karnataka Coast

\begin{tabular}{llllll}
\hline Diet components & \% Frequency & \% Weight & \% Number & Index of Relative Importance (IRI) & \% IRI \\
\hline Fish (Pooled) & 72.13 & 88.10 & 78.00 & 1509.60 & 91.22 \\
Partially digested unidentified fish & 24.59 & 43.29 & 14.00 & 808.58 & 48.86 \\
Decapterus russeli & 13.11 & 15.48 & 19.67 & 460.94 & 27.85 \\
Priacanthus spp. & 3.28 & 7.21 & 10.67 & 58.60 & 3.54 \\
Bregmoceros sp. & 4.92 & 0.45 & 11.33 & 57.95 & 3.50 \\
Rastrelliger kanagurta & 3.28 & 5.18 & 8.33 & 44.31 & 2.68 \\
Saurida sp. & 3.28 & 4.50 & 1.67 & 20.22 & 1.22 \\
Encrasicholina devisi & 4.92 & 1.72 & 1.67 & 16.64 & 1.01 \\
Odonus sp. & 3.28 & 3.56 & 1.33 & 16.05 & 0.97 \\
Epinephelus diacanthus & 1.64 & 2.69 & 3.67 & 10.42 & 0.63 \\
Lagocephalus inermis & 1.64 & 2.20 & 3.33 & 9.07 & 0.55 \\
Sardinella longiceps & 1.64 & 0.62 & 0.67 & 2.10 & 0.13 \\
Megalaspis cordyla & 1.64 & 0.94 & 0.33 & 2.09 & 0.13 \\
Apogon sp. & 1.64 & 0.05 & 0.67 & 1.17 & 0.07 \\
Trichiurus lepturus & 1.64 & 0.16 & 0.33 & 0.81 & 0.05 \\
Atul mate & 1.64 & 0.06 & 0.33 & 0.65 & 0.04 \\
\hline
\end{tabular}

Table 2 : Proximate composition of C. hippurus collected during 2017-18 in south-eastern Arabian Sea along Karnataka coast

\begin{tabular}{lllll}
\hline Months & Moisture $(\%)$ & Protein $(\%)$ & Fat $(\%)$ & Ash $(\%)$ \\
\hline Aug. 17 & 77.83 & 19.30 & 1.92 & 0.95 \\
Sep. & 80.10 & 18.00 & 0.9 & 1.0 \\
Oct. & 78.07 & 18.50 & 2.1 & 0.83 \\
Nov. & 78.07 & 19.00 & 2.1 & 0.83 \\
Dec. & 76.83 & 20.20 & 1.77 & 1.20 \\
Jan.18 & 77.90 & 19.64 & 1.64 & 0.82 \\
Feb. & 80.35 & 18.20 & 0.90 & 1.20 \\
Mar. & 77.80 & 19.80 & 1.30 & 1.10 \\
Apr. & 77.02 & 20.00 & 2.30 & 0.68 \\
May & 76.80 & 20.50 & 2.40 & 0.30 \\
Mean \pm S.E. & $78.07 \pm 1.24$ & $19.3 \pm 0.29$ & $1.73 \pm 0.18$ & $0.89 \pm 0.09$ \\
\hline
\end{tabular}


stomachs of dolphin fish indicates that it feeds at surface as well as in the columnar waters (Brewton et al., 2016).

Of the major diet components, cephalopods (squids, cuttlefish and octopus) were the second most important food constituent of dolphin fish (Table 1). Squids represented the major portion (7.24\% of IRI) of cephalopods compared to cuttlefish (IRI of $1.01 \%$ ) and octopus (IRI of $0.13 \%$ ). The possibilities of squids being consumed by this species during their diel vertical migrations towards the surface at night was reported by Brewton et al. (2016). Crustaceans consisting of crabs and shrimps formed very less quantity as diet and the results of previous studies are in agreement with present observations and reported the minor role of cephalopods and crustaceans as diet components of dolphin fish (Olson and Galvan-Magana, 2002; Pimenta et al., 2014).

Monthly variations in muscle proximate composition of $C$. hippurus are presented in Table 2. The moisture content (\%) fluctuated from 76.80 (May) to 80.35 (February) with mean values of $78.07 \pm 1.24$. The values obtained in the present study are comparable with the moisture content (\%) estimated for dolphin fish caught in the Pacific Ocean with its range from 77.8-80.3 with the mean values of 79.3 (Boiteanu, et al., 2014).

The ash content (\%) was maximum during December and February (1.2) and minimum during May (0.3) with an average value of 0.89 . The findings of this study indicated that the mean ash content $(1.4 \%)$ recorded for dolphin fish is high in Pacific Ocean (Boiteanu et al., 2014). The muscle composition of $C$. hippurus revealed that the protein content varied between $18.0 \%$ (September) to $20.5 \%$ (May) with mean value of $19.3 \%$ indicating that the fish can be considered as a good table fish (Viji et al., 2015). The value recorded in the present study is slightly higher

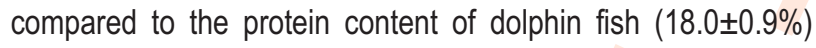
harvested from Pacific Ocean (Boiteanu et al., 2014). Protein content of the muscle varies widely depending on factors such as feeding habits and availability of food, fasting, migration etc.

The lipid content varied from $0.9 \%$ (September) to $2.4 \%$ (May), with an average value of $1.73 \%$ which was significantly high compared to the dolphin fish caught from Pacific waters $(0.9 \%)$ (Boiteanu et al., 2014). The difference in the lipid content could be due to the fish caught from different locations with varied environmental conditions.

The inverse relationship of moisture content with lipid and protein recorded for dolphin fish is in conformity with the observations of earlier investigation (Winfre and Stickney, 1981). The possible factor such as size, sex, maturity stage can affect the differences in proximate composition of marine fish.

The comprehensive information on length-weight relationship and feeding behaviour of dolphin fish would be a useful tool for subsequent population studies and stock assessment as it is a pre-requisite for developing suitable management plans for the conservation and cautious exploitation of this commercially important resource. Proximate composition estimated for different season provides an update to food composition database and would be useful for the consumer in choosing the fish based on their nutritional values.

\section{Acknowledgments}

The authors convey their heartfelt thanks to Nataraja, G. D., and Abdul Hakim, staff of Mangalore Research Centre, ICARCMFRI, for the help rendered in the collection of specimen and taking up the biological analysis in the laboratory.

\section{References}

AOAC: Official Methods of Analysis of Association of Official Analytical Chemists. $18^{\text {th }}$ Edn., Washington, D.C. (2010).

Boggs, C.H.: Depth, capture time and hooked longevity of long-line caught pelagic fish: Timing bites of fish with chips. Fish. Bull., U.S., 90, 642-658 (1992).

Boiteanu, C.N., M. Manthey-Karl, H. Karl, C. Meyer and C. Savu: Proximate composition, microbiological quality and sensory attributes of mahi-mahi (Coryphaena hippurus) and Emperor Sea bream (Lethrinus spp.) fillets sold on retail market. Bull. UASVM Food Sci. Tech., 71, 89-95 (2014).

Brewton, R.A., M.J. Ajemian, P.C. Young and G.W. Stunz: Feeding ecology of dolphinfish in the western Gulf of Mexico. Trans. Am. Fish. Soc., 145, 839-853 (2016).

Castriota, L., C. Pipitone, S. Campagnuolo, M. Romanelli, A. Potoschi and F. Andaloro: Diet of Coryphaena hippurus (Coryphaenidae) associated with FADs in the lonian and Southern Tyrrhenian Seas Cybium, 31, 435-441 (2007).

Chuen-Chi, Wu., S.U. Wei-Cheng and K. Tsuyoshi: Reproductive biology of the dolphin fish Corphaena hippurus on the east coast of Taiwan. Fish. Sci., 67, 784-793 (2001).

Collette, B., A. Acero, , A.F. Amorim, A. Boustany, C.C. Ramirez, G. Cardenas, K.E. Carpenter, N. Jr. de Oliveira Leite, A. Di Natale, W. Fox, F.L. Fredou, J. Graves, F.H. Vierahazin, M. Juan Jorda, C. Minte Vera, N. Miyabe, R. Montano Cruz, R. Nelson, H. Oxenford, K. Schaefer, R. Serra, C. Sun, R.P. TeixeiraLessa, P.E. Pires Ferreira Travassos, Y. Uozumi and E. Yanez: Coryphaena hippurus. The IUCN Red List of Threatened Species (2011): eT154712A4614989. http://dx.doi.org/10.2305/IUCN.UK. 20112.RLTS.T154712A4614989.en.

Froese, R.: Cube law, condition factor and weight-length relationships: History, meta-analysis and recommendations. J. Appl. Ichthyol., 22, 241-253 (2006).

Froese, R. and D. Pauly: Fish Base. World Wide Web Electronic Publication. http://www.fishbase.org (2017).

FWRI: Dolphin general facts. Fish and Wildlife Research Institute, Florida, pp. 55-58 (2008)

Gatt, M., M. Dimech and P.J. Schembri: Age, growth and reproduction of Coryphaena hippurus (Linnaeus, 1758) in Maltese waters, Central Mediterranean. Medit. Mar. Sci., 16, 334-345(2015).

Juanes, F. and D.O. Conover: Rapid growth, high feeding rates and early piscivory in young of the year blue fish Pomatomus saltatrix. Can. 
J. Fish. Aquat. Sci., 51, 1752-1761 (1994).

Le Cren, E.D.: The length-weight relationship and seasonal cycle in the gonad weight and condition in the perch (Perca fluviatilis). J. Anim. Ecol., 20, 201-219 (1951).

Massuti, E., S. Deudero, P. Sanchez and B. Morales-Nin: Diet and feeding of dolphin (Coryphaena hippurus) in Western Mediterranean waters. Bull. Mar. Sci., 63, 329-341 (1998).

Olson, R. and F.G. Magana: Food habits and comparison rates of common dolphinfish Coryphaena hippurus in the eastern Pacific Ocean. Fish. Bull., 100, 279-298 (2002).

Oxenford, H.A. and W. Hunte: Age and growth of dolphin, Coryphaena hippurus, as determined by growth rings in otoliths. Fish. Bull., 81, 906-909 (1983).

Oxenford, H.A.: Biology of the dolphinfish Coryphaena hippurus in the western central Atlantic, a review. Sci. Mar., 63, 277-301 (1999).

Pimenta, E.G., Y.C. Vieira, L.A. Marques, T.X. Gomes and A.F. Amorim: Analysis of stomach contents of dolphin fish Coryphaena hippurus, (Linnaeus, 1758) Actinopterygii, Coryphaenidae off the northern coast of Rio de Janeiro State, Brazil. Collect. Vol. Sci. Pap. ICCAT, 70, 2954-2960 (2014).

Pinkas, L., M.S. Olipahnt and I.L.K. Iverson: Food habits of albacore, bluefin tuna and bonito in Californian waters. Fish. Bull., 152,1-105 (1971).

Rajesh, K.M., R. Prathibha, K.G. Mini, T. Sathyavathi and M.M. Abdul Hakeem: Seriolina nigrofasciata (Ruppel, 1829), its fishery and biological aspects off south-west coast of India (Bloch, 1790). Indian J. Fish., 66, 9-16 (2019).

Snedecor, G.W. and W.G. Cochran: Statistical Methods. VI $\left.\right|^{\text {th }}$ Edn., Oxford and IBH Publishing Co. , New Delhi, p. 593 (1967).

Viji, P., S. Tanuja, G. Ninan, K.V. Lalitha, A.A. Zynudheen, P.K. Binsi and T.K. Srinivasagopal: Biochemical, textural, microbiological and sensory attributes of gutted and ungutted sutchi catfish (Pangasianodon hypophthalmus) stored in ice. J. Food Sci. Technol., 52, 3312-3321 (2015).

Vinod Kumar, M., M.K. Farejiya, K.S. Mali, K.C. Sahu and T. Rahul Kumar: Observations on the food preferences, growth parameters and biological aspects of Coryphaena hippurus Linnaeus, 1758 exploited through the longline survey operations along the West coast of India. Int. J. Fish. Aquat. Stud., 5, 240-248 (2017).

Winfre, R.A. and R.R. Stickney: Effect of dietary proteins and energy on growth feed conversion efficiency and body composition of Tilapia aurea. J. Nutr., 111, 1001-1012 (1981). 